\title{
PEMANFAATAN MEDIA SOSIAL PADA SEKAA TRUNA TRUNI PARA GOTRA SENTANA DALEM TARUKAN (STT PGSDT) SEBAGAI MODEL INTERAKSI BERBASIS IT DI BANJAR DINAS MELAKA BULELENG, BALI
}

\author{
Gede Wiga Anggara Ariasa ${ }^{1}$, Luh Putu Sendratari, M.Hum², I Gusti Made Arya Suta \\ Wirawan, S.Hum M.Si ${ }^{3}$ \\ Program Studi Pendidikan Sosiologi \\ Jurusan Sejarah / Sosiologi / D3 Perpustakaan \\ Fakultas Hukum Dan IImu Sosial \\ Universitas Pendidikan Ganesha \\ Singaraja, Indonesia
}

Email : \{gedewigaa@gmail.com¹, Ipsendra@yahoo.com², arthasutha@yahoo.com³\}.

\begin{abstract}
Abstrak
Media sosial merupakan media online dengan para penggunanya mudah berinteraksi dalam dunia virtual (dunia maya). Zaman semakin berkembang dengan terciptanya media sosial, yang memudahkan masyarakat berkomunikasi tanpa terhalang jarak dan waktu. Media sosial saat menjadi kebutuhan wajib bagi masyarakat, karena tanpa adanya media sosial, masyarakat tidak bisa mengetahui berita dan informasi yang terbaru. Media sosial memiliki beberapa fungsi yaitu digunakan dalam bisnis, hiburan dan termasuk juga dalam organisasi kepemudaan. Organisasi kepemudaan merupakan lembaga yang menghimpun segenap potensi anak muda yang akan mendidik mereka dengan tujuan menjadi berguna dalam kehidupan bermasyarakat. Organisasi kepemudaan berdiri bersama dengan visi, misi dan beberapa aturan yang mengikat para anggotanya. Organisasi kepemudaan menggunakan media sosial sebagai alat bantu komunikasi dengan tujuan mempermudah komunikasi yang dilakukan oleh para anggota organisasi. Para anggota yang mayoritas sudah mempunyai sosial media akan dengan cepatnya mendapatkan informasi terkait dengan kegiatan di organisasi.
\end{abstract}

Kata Kunci : Media Sosial, Organisasi Kepemudaan, Interaksi Sosial

\begin{abstract}
Social media is an online media with its users easily interacting in a virtual world (cyberspace). Times are develop, with the created of social media, which makes it easy for people to communicate without limit of distance and time. When social media becomes a mandatory requirement for the community, because without social media, the public can't see the news and information. Social media has several functions which are used in business, entertainment and also included in youth organizations. Youth organizations are institutions that gather all the potential of young people who will educate them with the aim of becoming useful in social life. Youth organizations stand together with a vision, mission and some rules that bind their members. Youth organizations use social media as a communication tool with the aim of facilitating communication made by members of the organization. Members who have a majority of social media will quickly get information related to activities in the organization.
\end{abstract}

Keywords : Social Media, Youth Organization, Social Interaction 


\section{PENDAHULUAN}

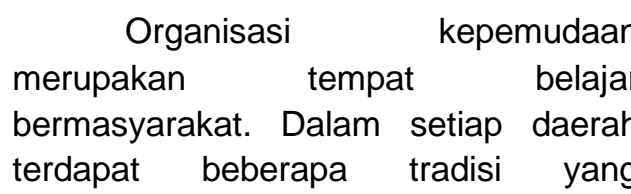
diwariskan secara turun temurun, anggota dalam organisasi secara langsung melestarikan tradisi tersebut. Dalam upacara Agama Hindu seperti odalan. Organisasi kepemudaan menjadi aktif berkegiatan untuk memperlancar jalannya upacara. Pembentukan STT sebagai organisasi kepemudaan juga mengurangi kenakalan remaja, karena dalam STT dilatih untuk bagaimana berorganisasi dan secara langsung belajar untuk bermasyarakat. Dalam organisasi kepemudaan melatih kemampuan komunikasi (Public Speaking) yaitu berbicara didepan umum.

$\begin{array}{rrrr}\text { STT } & \text { (Sekaa } & \text { Truna } & \text { Truni) } \\ \text { merupakan } & \text { budaya } & \text { asli } & \text { yang }\end{array}$
berdasarkan pada yadnya (tulus ikhlas) serta tanpa mengharapkan imbalan. Ketika seseorang sudah siap untuk mengikuti organisasi tersebut, melaksanakan ritual bernama "menek daha/truna". Dengan menghaturkan sebuah upakara bernama "pras daksina" serta memberitahukan diri kepada sesuhunan yang berstana di pura tersebut bahwa siap untuk ngayah (tradisi gotong royong di Bali) pada setiap piodalan (kegiatan adat). Sebagai mahluk sosial tentunya manusia membutuhkan manusia lain untuk melangsungkan kehidupannya. John M. Shepard (1974) Pola komunikasi pada anggota bersifat langsung ataupun tidak langsung.

Sekaa Truna Truni merupakan organisasi berbasis masyarakat adat diikat oleh kesatuan tradisional, anggotanya melibatkan anak yang sudah beranjak dewasa yaitu 12 tahun serta belum menikah. Dalam organisasi sekaa teruna-teruni tokoh masyarakat berperan sangat penting

Berdasarkan data organisasi dari kelian dusun $\mathrm{Br}$. Dinas Melaka pada tahun 2018. Sekaa Truna Truni Para Gotra Sentana Dalem Tarukan (selanjunya disingkat STT PGSDT) terbentuk pada tahun 2018 di mana dipimpin oleh Putu Eka Damayani. Dalam STT PGSDT terdapat keliat adat (ketua adat) yaitu Made Sudarma, serta kelian dadia (ketua dadia) Nengah Mertama, di mana beliau senantiasa membimbing STT PGSDT untuk menjadi lebih baik lagi dalam menjalankan kewajibannya. Hal yang terpenting dalam organisasi adalah komunikasi, di mana dalam STT PGSDT ini memerlukan komunikasi langsung kepada anggota yang bersangkutan, namun kenyataannya organisasi ini melakukan adaptasi terhadap kehadiran Informasi Teknologi (IT). Anggota dari STT PGSDT ini sebagian ada yang bekerja dan sebagian ada yang masih menempuh pendidikan hal itu sedikit sulit apabila melakukan komunikasi secara langsung, sehingga memanfaatkan kehadiran IT untuk mempermudah komunikasi antar anggota anggota STT PGSDT.

Perbandingan STT PGSDT dengan organisasi pada umunya yaitu STT PGSDT dibentuk berdasarkan garis keturunan (Klan) Para Gotra Sentana Dalem Tarukan, para anggota merupakan satu sanggah tunggalan (tempat sembahyang berdasarkan Klan). Dalam perekrutan anggota terdapat beberapa persyaratan mutlak yaitu anggota harus merupakan keturunan dari Para Gotra Sentana Dalem Tarukan, umur minimal 12 tahun, belum menikah, serta mahir menggunakan internet. Pada umumnya organisasi kepemudaan tidak terlalu mementingkan Klan atau keturunan 


\section{METODE PENELITIAN}

Penelitian tentang "Pemanfaatan Media Sosial Pada Sekaa Truna Truni Para Gotra Sentana Dalem Tarukan (STT PGSDT) Sebagai Model Interaksi Berbasis It Di Banjar Dinas Melaka Buleleng, Bali, menggunakan pendekatan deskriptif-kualitatif dengan metode pengumpulan data menggunakan observasi, wawancara dan studi dokumen. Subyek penelitian yaitu ketua dan anggota STT PGSDT yang sudah terbiasa menggunakan media sosial

\section{HASIL DAN PEMBAHASAN}

\section{Gambaran Umum Lokasi} Penelitian

$\begin{array}{ccr}\text { Desa } & \text { Kayuputih Melaka } \\ \text { merupakan Desa di Kecamatan }\end{array}$ Sukasada, Kabupaten Buleleng. Desa Kayuputih Melaka terletak di ketinggian 400 meter dari permukaan air laut dengan topografi bentangan wilayah dataran rendah mencapai 158 hektar/ meter persegi, dataran tinggi mencapai 109 hektar/meter persegi. Penduduk Desa Kayuputih Melaka berjumlah 4.305 Jiwaterdiri dari 2.180 laki-laki. Desa Kayuputih Melaka hanya bisa dilewati oleh kendaraan pribadi. Waktu tempuh yang dibutuhkan untuk sampai ke pusat fasilitas terdekat (Ekonomi, Kesehatan, Pemerintahan) kurang lebih 30 menit. Jarak tempuh Desa Kayuputih Melaka dengan ibu kota Kecamatan Sukasada berjarak $18 \mathrm{~km}$ yang dapat ditempuh dalam waktu kurang lebih 31 menit menggunakan kendaraan bermotor. Jarak Desa Kayuputih menuju Kabupaten Buleleng berjarak $16 \mathrm{~km}$ dapat ditempuh dalam waktu kurang lebih 27 menit menggunakan kendaraan bermotor. Sedangkan jarak Desa Kayuputih Melaka dengan ibu kota Provinsi Denpasar berjarak $80 \mathrm{~km}$, dapat ditempuh dalam waktu 1 jam 58 menit menggunakan kendaraan bermotor. (Profil Desa Kayuputih Melaka, 2017:7). Desa Kayuputih Melaka memiliki beberapa Dusun yang terdiri dari
1. Dusun Buanasari (Utara)
2. Dusun Sinalud (Barat)
3. Dusun Panti (Timur)
4. Dusun Kayuputih (Tengah)
5. Dusun Melaka (Selatan)

\section{Latar Belakang Penggunaan Media Sosial di STT PGSDT Melihat perkembangan teknologi komunikasi yang memudahkan komunikasi, sehingga media sosial dipilih sebagai alat bantu pada organisasi. Terdapat beberapa alasan mengapa aplikasi WhatsApp sangat digemari yaitu dilihat pada tabel 01}


Jurusan Sejarah, Sosiologi dan Perpustakaan (Volume 2, Nomor 2, Tahun 2020)

Tabel 01

Jawaban Responden Mengenai Media Sosial

\begin{tabular}{|c|c|c|c|}
\hline Nama & Media S & & Alasan \\
\hline \multirow{3}{*}{ Gede Mahaendrayasa (18) } & Facebook & & \multirow{3}{*}{$\begin{array}{l}\text { Cukup menyimpan } \\
\text { nomor telepon dan } \\
\text { langsung terlihat kontak } \\
\text { whatsapp }\end{array}$} \\
\hline & Instagram & & \\
\hline & WhatsApp & $\checkmark$ & \\
\hline \multirow{3}{*}{ Ketut Sri Nuriantini (17) } & Facebook & & \multirow{3}{*}{$\begin{array}{l}\text { Cukup dengan } \\
\text { mengetik nama kontak, } \\
\text { langsung terlihat kontak } \\
\text { whatsapp yang akan } \\
\text { dituju }\end{array}$} \\
\hline & Instagram & & \\
\hline & WhatsApp & $\checkmark$ & \\
\hline \multirow{5}{*}{ Kadek Suardiasa (18) } & Facebook & & \multirow{5}{*}{$\begin{array}{l}\text { Semua orang pasti } \\
\text { pakai WA, bahkan } \\
\text { wajib punya WA, } \\
\text { jadinya kita gampang } \\
\text { komunikasi pakai WA. } \\
\text { Kalau WA sekarang } \\
\text { udah kayak Instagram, } \\
\text { bisa buat story lah, bisa } \\
\text { video call atau apa lah }\end{array}$} \\
\hline & Instagram & & \\
\hline & WhatsApp & $\checkmark$ & \\
\hline & Instagram & & \\
\hline & WhatsApp & $\checkmark$ & \\
\hline
\end{tabular}

Penggunaan media sosial di STT PGSDT pastinya punya tujuan yang positif, Penggunaan Instagram disampaikan oleh admin Gede Eka Sukma Saputra (15) 18 Juli 2019 dinyatakan:

"Jaman sekarang banyak orang yang pakai Instagram, kalau ada apa-apa pasti cepet banget nyebar, selain itu Instagram sangat mudah untuk dipakai, tinggal ambil foto atau pilih foto kemudian upload dan foto sudah terpublikasikan. Di STT ini saya sebagai admin harus benar-benar teliti, karena yang harus diunggah memang benarbenar merupakan kegiatan STT PGSDT dengan tujuan supaya lebih dikenal luas.
Dalam teori komunikasi massa sseseorang atau organisasi yang benarbenar menyusun sebuah pesan dan mengirimkan melalui beragam media kepada khalayak luas yang anomim dan heterogen.

Menurut Effendy (1993) fungsi komunikasi tidak terlepas dari

a. Informasi

Jika melihat yang terjadi di STT PGSDT, fungsi informasi sudah mulai berjalan dengan baik, karena dalam penyapaian informasi tidak perlu yang namanya surat menyurat ke masing-masing individu.

b. Pendidikan

Melihat di STT PGSDT secara langsung para 
Jurusan Sejarah, Sosiologi dan Perpustakaan (Volume 2, Nomor 2, Tahun 2020)

anggota belajar bagaimana cara menjadi bagian dari masyarakat.

c. Mempengaruhi

Fungsi tersebut akan terasa apabila yang tidak bisa hadir tanpa alasan yang jelas, maka akan terpengaruhi saat melihat foto di grup whatsapp, Instagram, dan facebook, yaitu pada saat melihat fotofoto narsis ataupun foto-foto candid (foto tanpa gaya \& tanpa disengaja), maka yang tidak hadir akan merasa minder karena wajah tidak ada dalam foto tersebut.

d. Menghibur

Fungsi ini pula terjadi pada STT PGSDT, dimana dalam media sosial admin terkadang menyimpan foto-foto aib (foto tidak bagus) sehingga akan menjadi bahan untuk tertawa, kesesama anggota grup, dalam postingan di Instagram admin pula akan memposting bagaimana keseruan bercanda pada saat ngayah dan pada saat kegiatan tertentu.

3. Model Interaksi Sosial Yang Digunakan Di STT PGSDT

Sebelum menuju ke model interaksi di STT PGSDT, terlebih dahulu penjelasan tentang Model Interaksi sosial Gestalt yaitu fokus pada hubungan harmis antara individu dan masyarakat (Octaviani,2013:01) Interaksi Sosial Gestalt merupakan Pokok pandangan objek atau peristiwa tertentu akan dipandang sebagai suatu keseluruhan yang terorganisasikan. Makna suatu objek/peristiwa adalah terletak pada keseluruhan bentuk (Gestalt) dan bukan bagianbagiannya.

Penerapan Model Interaksi Gestalt adalah sebagai berikut (Octaviani, 2013:01)
1. Pengalaman insight (wawasan)

2. Pengalaman yang bermakna

3. Perilaku yang bertujuan

4. Prinsip ruang hidup

Menurut Joseph De Vito dalam (Subani, 2013:01) dijelaskan terdapat beberapa unsur komunikasi. Dalam media social terdapat unsur komunikasi yang berlangsung, di masing masing anggota STT PGSDT diantaranya dalam

1. Komunikator Komunikator merupakan pengirim pesan. Dalam STT PGDT ketua berperan sebagai komunikator, Ketua akan memberi arahan kepada anggota untuk melaksanakan yang sudah diperintahkan.

2. Pesan atau Informasi

Keseluruhan yang disampaikan oleh komunikator. Pesan dan informasi bisa berupa gambar, tulisan dsb.

3. Sarana Komunikasi

Penyalur pesan dalam proses komunikasi. Penyalur pesan merupakan alat bantu yang mempermudah komunikasi. Dalam STT PGSDT Media Sosial menjadi sarana komunikasi

4. Komunikan

Merupakan penerima pesan yang disampaiakan oleh komunikator. Anggota STT PGSDT menerima pesan dari ketua STT PGSDT

5. Umpan Balik

Jawaban yang diberikan oleh komunikan kepada komunikator.

Tujuan yang dicapai oleh anggota ataupun ketua dari STT PGSDT yaitu Membentuk Komunitas Sosial, media sosial sebagai sarana dalam membangun interaksi antar komunitas. Dalam memakai media social, STT PGSDT mampu memanfaatkan perkembangan teknologi dengan membuat organisasi berbasis IT yaitu STT PGSDT. Dalam STT PGSDT 

Jurusan Sejarah, Sosiologi dan Perpustakaan (Volume 2, Nomor 2, Tahun 2020)

interaksi ini berlangsung baik secara face to face (berhadapan langsung) maupun secara tidak langsung. Interaksi secara tidak langsung tentunya terjadi di media sosial. Manusia sebagai mahluk sosial tentunya memerlukan manusia lain untuk melangsungkan kehidupannya. Manusia membutuhkan manusia lain tercipta melalui interaksi. Pengertian interaksi yaitu saling terhubung atau saling berhubungan. Media sosial digunakan secara optimal untuk mempermudah komunikasi di STT PGSDT

Organisasi tidak akan lengkap jika tidak ada aturan yang dijadikan pedoman untuk menjadi anggota. Berikut pengakuan Kelian adat Bapak Made Sudarma (56) 18 Juli 2019 tentang aturan di STT PGSDT:

"Dalam menangani anggota
yang malas maka
konsekuensinya adalah sanksi
sosial, Jika anggota yang tidak
hadir tersebut mempunyai
kesibukan, maka pasti akan
kesulitan, karena hanya
menghadapinya seorang diri.
Jika nanti yang jarang hadir
menikah, maka saya akan
perhambat untuk mendapat
tanda tangan untuk persetujuan
kelian adat"

Model Interaksi sosial Gestalt yaitu fokus hubungan harmonis antara individu dan masyarakat.Sangatlah relevan untuk organisasi kepemudaan karena dalam menyelesaikan masalah manusia tidak akan pernah bisa melakukannya sendiri, akan lebih mudah jika dilakukan secara bersamasama. Mengacu pada konsep kearifan lokal di Bali. Penggunaan media sosial tentunya ada aturan yang berlaku dalam artian tidak seenaknya menggunakan media sosial, terdapat beberapa hal-hal yang tidak boleh dibahas di STT PGSDT.

Dalam STT PGSDT interaksi merupakan hal yang paling utama. (Bungin, 2006 : 55) terdapat 2 (dua) syarat untuk terjadinya interaksi sosial

\section{Kontak Sosial}

Hubungan satu orang atau lebih melalui percakapan (Abdulsyani, 2012: 154). Percakapan yang terjadi di media sosial, berisi tentang bagaimana membicarakan hal penting tetang bagaimana persiapan kegiatan adat yang melibatkan STT PGSDT.

\section{Komunikasi}

Komunikasi merupakan proses pengiriman pesan dari komunikator dan komunikan (Suranto, 2012 : 02). Dalam STT PGSDT yang bertugas sebagai komunikator (sumber) adalah ketua, sekretaris, dan bendahara. Ketua bertugas memberi informasi tentang apa yang harus dilakukan seperti misalnya ngayah pada hari yang telah ditentukan.

sejenis $\begin{gathered}\text { Komunikasi juga memiliki } \\ \text { struktur, karena dalam }\end{gathered}$ organisasi terdapat pengurus inti dan anggota. Dalam grup WhatsApp STT PGSDT aturan tersebut tidak berlaku, yaitu semua anggota semua ikut dalam forum komunikasi tersebut, berdasarkan wawancara dengan ketua STT PGSDT Eka Damayani (21) pada Rabu 07 Juli 2019 yaitu:

"Tidak ada pengurus inti, semua ikut dalam forum komunikasi tersebut, dengan tujuan semua mengetahui apa yang dibahas, karena kita semua merupakan keluarga atau lebih tepatnya generasi muda yang akan memelihara dadia Dalem Tarukan"

Organisasi kepemudaan merupakan wadah untuk menampung generasi muda. Anak muda punya kecenderungan untuk berkumpul. Tujuan anak muda untuk berkumpul yaitu untuk mengekspresikan diri dengan lingkungannya. Dilihat dari tahapan sosialisasi untuk pembentukan kepribadian yaitu

a. Game Stage 
Jurusan Sejarah, Sosiologi dan Perpustakaan (Volume 2, Nomor 2, Tahun 2020)

Tahap sudah mengetahui, memahami dan menjalankan perannya dalam berinteraksi dengan orang lain. Dalam STT PSDT, masing-masing anggota menjalankan perannya masing-masing kemudian berinteraksi dengan anggota lain dengan peran yang lain dan saling melengkapi.

b. Generalized Stage

Tahap menerima norma kolektif dimana individu sudah menjadi warga masyarakat yang sesungguhnya dalam dalam menjalankan status serta perannya ketika berada dalam lingkungan masyarakat dan berinteraksi dengan masyarakat, pada tahap ini individu sudah dianggap dewasa dan menempatkan dirinya dalam masyarakat. Dalam STT PGSDT tahap ini juga melekat pada Ketua STT, dimana dengan usia 20 tahun sudah dianggap cukup dewasa dan matang untuk memimpin dan mengarahkan organisasi kepemudaan.

Dalam organisasi kepemudaan tahaptahap sosialisasi tersebut sangatlah penting, karena sosialisasi akan terjadi proses interaksi dan tempat belajarnya para anggota. Berikut merupakan kegiatan ngayah sebelum hari raya galungan

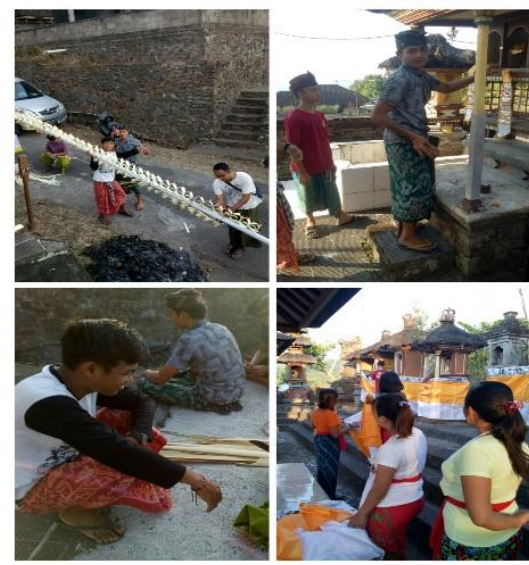

Gambar 4.2

Suasana Ngayah Di Sanggah Tunggalan PGSDT (Sumber : Pribadi)

Organisasi STT PGSDT merupakan sekumpulan individu yang saling berinteraksi. STT PGSDT sekumupan individu yang terikat dengan peraturan di STT PGSDT mereka saling berinteraksi dalam satu wadah yaitu organisasi kepemudaan STT PGSDT. Dalam organisasi di STT PGSDT para anggota saling bekerja sama dalam membangun organisasi menjadi lebih baik lagi. Saling mempengaruhi berarti masingmasing anggota memberi pengaruh kepada anggota lain kemudian, ketua memberi pengaruh positif kepada anggotanya. Kelompok sosial memiliki beberapa ciri-ciri sebagai berikut

a. Terdapat kesadaran dan rasa memiliki

Seseorang yang bergabung dalam kelompok sosial, maka akan secara langsung memiliki kesadaran akan pentingnya menjadi bagian dari anggota kelompok tersebut. Dalam STT PGSDT anggota yang sudah tercatat namanya akan timbul rasa memiliki organisasi tersebut, seperti dibuatkan stiker untuk ditempel, selalu membagi info-info menarik, penting dan lucu (hiburan) ke grup WA STT PGSDT. 
b. Terdapat hubungan timbal balik

Dalam hubungan tersebut dapat diartikan sebagai memberi dan menerima. Dengan adanya hubungan tersebut akan tercipta kebersamaan antar anggota dan terjadi solidaritas kelompok. Dalam STT PGSDT hubungan timbal balik terlihat pada rapat yaitu saling memberi dan menerima masukan, baik itu masukan untuk kegiatan yang akan dilaksanakan maupun masukan tentang kegiatan yang sudah dilaksanakan atau sering disebut rapat evaluasi.

c. Adanya kepentingan bersama

Terdapat kesamaan yang mengikat antar anggota, kesamaan anggota kelompok dapat berupa kesamaan nasib, tujuan dan ideologi. Kepentingan bersama yang terjadi di STT PGSDT yaitu kepentingan untuk melestarikan budaya Bali dengan cara membentuk organisasi kepemudaan, menjaga persatuan antar soroh (keturunan) serta menjaga dan melestarikan dadia PGSDT Banjar Dinas Melaka.

d. Berstruktur, berkaidah dan mempunyai pola perilaku

Setiap kelompok terdapat peraturan yang harus ditaati dan memberikan sanksi bagi siapa yang melanggarnya. Sanksi yang terdapat di STT PGSDT berupa sanksi sosial, yang memberikan rasa takut bagi anggota untuk melanggarnya.
Sanksi merupakan hal penting dalam organisasi dengan tujuan memberikan efek jera bagi pelanggarnya. Sanksi juga membatasi kebebasan anggota kelompok, karena pada dasarnya tidak ada manusia yang bebas sebebas bebasnya, melainkan hanya bebas namun terbatas.

Terdapat pula beberapa alasan terbentuknya kelompok sosial diantaranya

a. Dorongan Untuk Bertahan Hidup Manusia bergabung dalam kelompok sosial untuk mempertahankan hidupnya,

b. Keinginan meningkatkan efisiensi dan efektivitas kerja

Dalam setiap kelompok ada pembagian kerja yang jelas. STT PGSDT ditunjuk langsung oleh ketua STT, selanjutnya anggota yang sudah mendapat bagian akan langsung melaksanakan tugasnya

c. Sarana Menjalin Hubungan Sosial

Kelompok sosial merupakan sarana berkumpulnya individu untuk saling berinteraksi. Para anggota di STT PGSDT bertujuan untuk saling beriteraksi, baik interaksi antara anggota dan sie yang bertugas, antara anggota dengan ketua, antara ketua dengan kelian adat 


$\begin{array}{lr}\text { dsb. } & \text { Hubungan } \\ \text { sosial yang } & \text { terjadi } \\ \text { dapat } & \text { berupa } \\ \text { komunikasi } & \text { yang } \\ \text { bertujuan } & \text { untuk } \\ \text { memperkuat } & \\ \text { koordinasi } & \text { antar } \\ \text { anggota } & \end{array}$

Melihat penjelasan diatas, media sosial merupakan sarana yang efektif untuk memperlancar komunikasi. Berdasarkan wawancara dengan Gede Mahaendrayasa (18 Tahun) Kamis 08 Agustus 2019

"Nyaman sih kalau pakai media sosial karena kita dapat chat atau video call sama teman atau pacar yang jauh, pakai media sosial, nyaman aja sih buat saya, kalau ada info dadakan biar gampang ya pakai wa aja"

Terdapat hal-hal tidak boleh dibahas di media sosial, karena hal tersebut dapat menyebabkan ketidaknyamanan pengguna media sosial. Berdasarkan wawancara dengan Eka Damayani selaku ketua STT PGSDT pada tanggal 09 Agustus 2019 yaitu

"Hal yang tidak boleh dibahas
seperti bercanda sampai
kelewatan, sampai membuat
orang lain merasa terganggu
dengan candaan kita yang
kurang penting, terus nge-post
foto foto kurang sopan, karena
semua orang yang masuk di
grup itu itu nanti yg lihat dan
yang terpenting grup itu
gunanya untuk membahas hal
yang penting"

Wawancara pula dilakukan bersama kelian adat PGSDT (Para Gotra Sentana Dalem Tarukan) Br. Dinas
Melaka, Made Sudarma (56) sekaligus pembimbing di STT PGSDT terkait dengan hal-hal yang tidak boleh dibahas dalam grup WA STT PGSDT, pada Jumat 09 Agustus 2019 yaitu:

"Bercanda boleh tapi jangan terlalu, sampai membuat teman lain jadi tersinggung, kalau kita ada masalah pribadi jangan diumbar digrup, biasanya ada yang keluar dari grup tanpa alasan, yang jelas kita boleh ribut, tapi ribut tentang kegiatan apa yang akan berjalan tidak masalah"

Hidup bermasyarakat tentunya individu diikat oleh peraturan dengan tujuan individu bisa hidup dengan tentram dan damai, pada prinsipnya tidak ada manusia yang bebas sebebas-beasnya, namun bebas terbatas. Peraturan tersebut pula di STT PGSDT, terutama di grup WA, yaitu ada peraturan yang harus ditaati untuk kenyamanan dalam menggunakan grup tersebut

Dalam hidup bermasyarakat tidak pernah terlepas dengan peraturan. Peraturan diciptakan dengan tujuan terjaganya keharmonisan dalam kehidupan bermasyarakat. Dalam bermasyarakat terdapat nilai sosial yang harus ditaati bersama. Nilai sosial adalah ukuran, patokan, atau anggapan hidup dan berkembang dalam masyarakat tertentu. Keyakinan tersebut dianut oleh individu yang hidup dalam masyarakat. Nilai sosial merupakan proses pembenaran dari masyarakat, yaitu terdapat 3 (tiga) diantaranya agama, masyarakat dan individu. Sedangkan menurut Dr. Notonegoro yaitu nilai material (benda), vital (penting) dan kerohanian (agama) 


\section{Kelebihan dan Kekurangan Penggunaan Media Sosial di STT PGSDT}

Media sosial memiliki kelebihan yang diaplikasikan di organisasi kepemudaan STT PGSDT. Media Sosial mempunyai beberapa manfaat di STT sebagai berikut (Cahyono, 2014: 104)

1. Mempermudah Interaksi

Dengan menggunakan HP yang mudah dibawa kemanamana, maka akan bisa langsung melakukan komunikasi tanpa ada batasan waktu. Berdasarkan wawancara dengan Ketua STT PGSDT Eka Damayani (22) pada 13 Oktober 2019 dinyatakan"Interaksi dilakukan disosmed supaya lebih mudah, walaupun pada sibuk bekerja, lagi ada kesibukan lain yang tidak bisa ditinggalkan, pasti akan tidak akan pernah lepas dari HP, sehingga pasti akan menerima notifikasi dari whatsapp. Info-info yang disebar ke grup whatsapp yang penting pasti akan masuk dan harus dibaca, jadi tidak ada alasan untuk tidak mengetahui info penting di grup"

\section{Sarana Hiburan}

Para anggota bisa mengirim video, link website yang berisi konten lucu yang sifatnya akan menghibur para anggota. Berdasarkan wawacara dengan Kadek Agus Sri Lesmana (18) pada $12 \quad$ Oktober 2019 dinyatakan"Banyak ada linklink video gokil, video gokil dari $\mathrm{fb}$, dari ig dan di tempat lain, itu fungsinya buat hiburan saja, kita bekerja pasti kita penat, suntuk, stress, jadi grup ini kita jadikan sebagai sarana hiburan, supaya para anggota semakin betah, semakin akrab dan semakin

Selain kelebihan yang berfungsi mempermudah komunikasi dan sebagai sarana hiburan, terdapat pula kekurangan dalam media sosial. Media sosial diciptakan oleh manusia, serta digunakan pula oleh manusia. Manusia sering terbuai dengan kecanggihan dan kepraktisan media sosial sehingga manusia menyalahgunakan. Penyalahgunaan media sosial ini yang banyak menimbulkan dampak negatif. (Abdillah Yafi Aljawiy \&, Ahmad Muklason, 05:2017) menyatakan ada beberapa kekurangan media sosial yaitu

a. Kurangnya Interaksi (individualis) Komunikasi secara langsung dengan lawan bicara cenderung menurun, hal tersebut disebabkan karena masyarakat lebih nyaman dan asyik menggunakan media sosial, dibanding berkomunikasi dengan orang disekitar. Dampak negative yang paling terlihat dari media sosial, yaitu medekatkan yang jauh namun juga menjauhkan yang dekat. Anggota STT PGSDT menjadi semakin individualis, karena pengaruh dari media sosial. Sifat individual terlihat pada saat sedang berkegiatan maupun tidak berkegiatan, yaitu kebanyakan bermain dengan ponselnya, seperti selalu ngambil foto secara berlebihan pada saat kegiatan berlangsung. Pada saat istirahat kegiatan kebanyakan anggota tidak mengobrol dengan teman disebelahnya, namun sibuk dengan ponselnya. Berdasarkan wawancara bersama Ketua STT PGSDT Eka Damayani (22) pada tanggal 13 Oktober 2019 dinyatakan "Pada saat kegiatan berlangsung kebanyakan anggota hanya ngambil foto aja kerjaannya, terus pada saat istirahat saya perhatikan tidak ada yang ngobrol sama teman disampingnya, tapi hanya sibuk dengan HP. Kalau ngobrol mereka 
e-Journal Pendidikan Sosiologi Universitas Pendidikan Ganesha Jurusan Sejarah, Sosiologi dan Perpustakaan (Volume 2, Nomor 2, Tahun 2020)

ngobrol, tapi masih saja memainkan HP. Itu pengaruh media sosial yang berdampak buruk yaitu menjauhkan yang dekat"

b. Mementingkan diri sendiri Jejaring sosial menyebabkan indivudu cenderung mementingkan kepuasan pribadi dibanding dengan orang lain. Hal tersebut terlihat pada saat berkumpul, sebagian besar memegang HP dan menggulir-gulir aplikasi media sosial yang menurut mereka menyenangkan, sedangkan orang di sekitar menjadi terabaikan

c. Penggunaan Bahasa yang baik dan benar

Dalam STT PGSDT kejadian tersebut terjadi yaitu pada saat pembuatan surat pernyataan tentang keluhankeluhan yang dirasakan selama di STT PGSDT. Berdasarkan wawancara bersama STT PGSDT Eka Damayani (22) pada tanggal 13 Oktober 2019 dinyatakan"Saat pembuatan surat pernyataan keluhan selama satu kepengurusan, saya sudah perintahkan mereka untuk membuat bahasa Indonesia yang baik dan benar, tapi kebanyakan (saya tidak menyebutkan nama) bahasanya singkat singkat dan jauh dari kata baik dan benar, mereka membuat pernyataan seperti membuat status di media sosial"

Penggunaan bahasa Indonesia merupakan hal paling terpenting dalam situasi yang bersifat formal, jika pengucapan bahasa kurang bagus, maka kita akan malu sebagai orang yang berpendidikan. Ketua STT PGSDT tidak sepenuhnya menyalahkan anggota yang belum mengerti dengan bahasa yang baik dan benar, karena sebagian dari mereka belum belajar tentang EYD (Ejaan Yang Disempurnakan) dalam Bahasa Indonesia.

d. Kesenjangan Informasi

Dalam STT PGSDT Kesenjangan Informasi yaitu, apabila ada anggota yang tidak ingat membuka grup STT
PGSDT sedangkan terdapat info-info penting mengenai kegiatan tertentu, maka disanalah akan terjadi kesenjangan dalam arti tidak mengetahui informasi dengan sengaja maupun tidak disengaja. Berdasarkan wawancara dengan anggota STT PGSDT Komang Ariasa alias Ari Cemong (17) pada 25 Oktober 2019 dinyatakan "Saya jarang sekali buka grup wa, saya dari pagi mencari makanan kambing saya, kadang siangnya saya kerja proyek, sekarang saya masih posisi kerja proyek, jadinya saya jarang bisa lihat info. Saya juga jarang bisa ikut kegiatan, karena saya baru datang dari kerja, capek sekali, ya ngerti saja"

Untuk mencegah efek negatif media sosial di STT PGSDT perlu adanya kesadaran menggunakan media sosial dengan bijak. Media sosial digunakan pada saat terhalang jarak dan waktu, apabila semua anggota sudah berkumpul, tidak ada lagi yang memegang HP dengan tujuan tidak menganggu kegiatan. Bukan berarti bahwa media sosial selalu memeberi dampak buruk. Cukup dengan menggunakan media sosial dengan bijak, niscaya media sosial akan menjadi hal positif yang mempermudah komunikasi

\section{PENUTUP}

\section{Rangkuman}

Media sosial merupakan media berosialisasi tanpa bertatap muka langsung. Media sosial tidak mengenal ruang, sehingga memudahkan masyarakat tidak bisa komunikasi lokal namun juga interlokal (luar negeri). Dalam pembelajaran sosiologi, media sosial erat kaitannya dengan materi pelajaran Interaksi Sosial, karena berkomunikasi di media sosial sendiri terdapat interaksi antar pengguna media sosial. Definisi interaksi secara umum yaitu, hubungan antara individu dengan yang individu lain dalam melangsungkan hidup di masyarakat sehingga dapat di katakan bahwa interaksi merupakan salah satu kebutuhan manusia. Sosial Media dapat memperluas dan memperpanjang relasi 
pertemanan penggunanya. Penggunaan media sosial tak lepas dari memudahkan interaksi. Hubungan sosial tersebut adalah berupa hubungan antara individu dengan individu lainnya, antara kelompok dengan kelompok lainnya, maupun antara kelompok dengan individu.

Dalam teori uses and gratifications mengasumsikan bahwa memuaskan kebutuhannya (Nurudin, 2003:181). Jika dikaitkan dengan konsep penggunaan media sosial, di mana para pengguna media sosial bisa dengan mudah berinteraksi satu dengan yang lainnya di suatu wadah yang sama seperti jejaring sosial. Pada penelitian ini, bahwa STT PGSDT memakai media sosial khususnya Whatsapp, Instagram \& Facebook sebagai medium untuk berinteraksi

Model yang di gunakan, yaitu Interaksi Sosial Gestalt yaitu fokus pada hubungan harmonis antara individu dengan masyarakat (learning to life together) (Octaviani, 2013). Interaksi Sosial Gestalt merupakan Pokok pandangan objek atau peristiwa tertentu akan dipandang sebagai suatu keseluruhan yang terorganisasikan. Makna suatu objek/peristiwa adalah terletak pada keseluruhan bentuk (Gestalt) dan bukan bagian-bagiannya. Aplikasi teori Gestalt dalam pembelajaran adalah sebagai berikut (Octaviani, 2013) Pengalaman insight (wawasan),Pembelajaran yang bermakna, Perilaku bertujuan. Perilaku terarah pada suatu tujuan, Prinsip ruang hidup (Life space). Dalam STT PGSDT interaksi ini berlangsung baik secara face to face (berhadapan langsung) maupun secara tidak langsung. Interaksi secara tidak langsung tentunya terjadi di media sosial. Model Interaksi sosial Gestalt yaitu fokus hubungan harmonis antara individu dengan masyarakat (learning to life together).

Penggunaan media sosial tentunya ada aturan yang berlaku dalam artian tidak seenaknya menggunakan media sosial, terdapat beberapa hal-hal yang tidak boleh dibahas di STT PGSDT.Dalam STT PGSDT interaksi merupakan hal yang paling utama. Jika mengacu pada syarat interaksi sosial yaitu ada kontak sosial dan komunikasi Burhan Bungin, (2006: 55).yaitu komunikasi \& kontak sosial

Selain kelebihan media sosial juga memiliki beberapa kekurangan sebagai berikut. (Abdillah Yafi Aljawiy \&, Ahmad Muklason, 05:2017) menyatakan ada beberapa kekurangan media sosial yaitu

1. Kurangnya Interaksi (individualis)

Anggota STT PGSDT menjadi semakin individualis, karena pengaruh dari media sosial. Sifat individual terlihat pada saat sedang berkegiatan maupun tidak berkegiatan, yaitu kebanyakan bermain dengan ponselnya, seperti selalu ngambil foto secara berlebihan pada saat kegiatan berlangsung.

2. Mentingkan diri sendiri Hal tersebut terlihat di STT PGSDT para anggota selalu mementingkan HP dari pada kegiatan yang lain, sehingga terkadang terjadi miss komunikasi

3. Penggunaan Bahasa yang baik dan benar

Ketua STT PGSDT tidak sepenuhnya menyalahkan anggota yang belum mengerti dengan bahasa Indonesia yang baik dan benar, karena sebagian dari mereka belum belajar tentang EYD (Ejaan Yang Disempurnakan) dalam Bahasa Indonesia.

4. Kesenjangan Informasi

Apabila ada anggota yang tidak ingat membuka grup STT PGSDT sedangkan terdapat info-info penting mengenai kegiatan tertentu, 
maka disanalah akan terjadi kesenjangan dalam arti tidak mengetahui informasi dengan sengaja maupun tidak disengaja

Untuk mencegah efek negatif media sosial di STT PGSDT perlu adanya kesadaran bagaimana menggunakan media sosial dengan bijak, yaitu dengan cara tidak berlebihan menggunakan media sosial dan menggunakan media sosial disaat membutuhkan saja

\section{Simpulan}

Kesimpulan dari penulisan skripsi dapat diuraikan sebagai berikut,

Faktor yang melatarbelakangi penggunaan media sosial di STT PGSDT yaitu karena media sosial sangat mudah menggunakanya serta siapapun sudah menggunakannya, terutama para pemuda. Terkhusus dalam STT PGSDT dalam organisasi tersebut melakukan adaptasi terhadap perkembangan IT sehingga model komunikasi dalam STT PGSDT berbasis IT (komunikasi melalui media sosial). Model komunikasi berbasis IT akan memudahkan cepatnya penyebaran informasi tanpa terhalang jarak dan waktu

Model interaksi yang digunakan di STT PGSDT yaitu berbasis IT. Pada masa sekarang semua sudah serba digital, terutama pada komunikasi di STT PGSDT. Dalam penggunaan media sosial tentunya ada beberapa peraturan yang harus ditaati, yaitu dalam grup whatsapp hanya membahas hal-hal yang berkaitan dengan kegiatan STT. Komunikasi dan kontak sosial terjadi di STT PGSDT yaitu komunikasi akan berlangsung di media sosial serta kontak sosial menjadi sebuah kesadaran dalam membangun STT PGSDT. Dalam model interaksi di STT PGSDT berkaitan dengan tahap sosialisasi yaitu game stage, play stage, dan generalized stage

Kelebihan yaitu bisa mempermudah komunikasi tanpa terbatas jarak dan waktu. Kekurangan yaitu harus selalu sedia kuota internet, jika tidak ada maka tidak bisa terhubung di media sosial, karena tidak bisa terhubung, maka tidak akan bisa mengetahui informasi penting di media sosial

\section{Saran}

Berdasarkan kesimpulan, maka terdapat saran yang dapat disampaiakan dari penulisan skripsi sebagai berikut,

Penggunaan media sosial harus berorientasi pada hal-hal yang lebih bermanfaat contohnya pada organisasi kepemudaan.

Model interaksi yang digunakan sudah berbasis IT, namun cara komunikasi yang lama jangan dilupakan begitu saja, seperti contohnya komunikasi menggunakan bahasa bali halus, kepada petinggi PGSDT (kelian adat, keliad dadia, jro mangku) serta bagaimana cara membuat surat undangan dengan menggunakan bahasa bali halus. Hal terpenting dalam penggunaan media sosial di STT PGSDT yaitu, harus cerdas menggunakan media sosial. Kendalikannlah media sosial, jangan sampai dikendalikan media sosial

Media sosial tentunya mempunyai kelebihan dan kekurangan, sebagai anak muda yang cerdas, maka harus bisa memaksimalkan kelebihan dalam menggunakan media sosial dalam organisasi kepemudaan. Kelebihan dalam menggunakan media sosial bisa dijadikan untuk sarana komunikasi berbasis IT untuk mempermudah komunikasi tanpa batas ruang dan waktu.

\section{DAFTAR PUSTAKA}

Abraham.Firda 2016 Pemanfaatan Media Online Terhadap Interaksi Sosial Masyarakat Diakses pada 23 mei 2019

Aingindra. (2009). Sejarah Perkembangan Teknologi Komunikasi, online, (http://www.aingindra.com/teknolo gikomunikasi.html,diakses pada 28 Maret 2016). 
Jurusan Sejarah, Sosiologi dan Perpustakaan (Volume 2, Nomor 2, Tahun 2020)

Arsyad, A. (2002). Media Pembelajaran. Jakarta: Raja Grafindo Persada.

Bungin, Burhan. 2006. Sosiologi Komunikasi: Teori Paradigma dan Diskursus Komunikasi di Masyarakat. Surabaya: Kencana.

Budiman. 2016. Makalah Pengaruh Sosial Media Terhadap Interaksi Sosial Masyarakat.http://

www.c3budiman.lol/2016/06/14/m akalah-pengaruh-sosial-mediaterhadap-interaksisosialmasyarakat/?i=1 (diakses $27 \mathrm{Mei}$ 2019, 15:44 WIB).

Cendektiawan B. Aziz. 2015 Efektifitas Penggunaan Sosial Media Twitter Sebagai Media Promosi Kesehatan (Analisis Epic Model Pada Follower Twitter @Infoimunisasi Pt. Biofarma (Persero). Yogyakarta: Universitas Sunan Kalijaga Yogyakarta (diakses 27 Mei 2019)

Dewi Nintya Dsk Putu. 2016. Peran Sekaa Teruna Dalam Mensosialisasikan Nilai-Nilai Akuntabilitas Berbasis Kearifan Lokal Tri Hita Karana (Studi Kasus Pada Sekaa Teruna Taruna Jaya Desa Pakraman Bangkang Baktiseraga Kecamatan Buleleng Kabupaten Buleleng Provinsi Bali Tahun 2016). Singaraja : Universitas Pendidikan Ganesha (diakses 27 Mei 2019)

Doyle Paul Johnson. 1986. Teori Sosiologi Klasik dan Modern. Jakarta: Gramedia. Eko Murdiyanto. 2008. Sosiologi Pedesaan. Yogyakarta: Wimaya PressUPN Veteran

Efendi. Agus dkk. Analisis Pengaruh Penggunaan Media Baru Terhadap Pola Interaksi Sosial Anak Di Kabupaten Sukoharjo. Diakses Pada 23 Mei 2019
Jamaludin Nasrullah. 2015. Sosiologi Perdesaan: Bandung: Pustaka Setia.

Hamzah E. Radja.2015. Penggunaan Media Sosial Di Kampus Dalam Mendukung Pembelajaran Pendidikan Wacana Volume XIV No.1, Cahyono S. Anang "Pengaruh Media Sosialterhadap Perubahan Sosialmasyarakat Di Indonesia" HIm 142-152 (diakses 27 Mei 2019)

Istiyanto, S.B. Telepon Genggam Dan Perubahan Sosial Studi Kasus Dampak Negatif Media Komunikasi Dan Informasi Bagi Anak-Anak Di Kelurahan Bobosan Purwokerto Kabupaten Banyumas.Jurnal Komunikasi Ikatan Sarjana Komunikasi Indonesia (2016).1:58-63.

Mahendra T. Ikhsan. 2017. Peran Media Sosial Instagram Dalam Pembentukan Kepribadian Remaja Usia 12-17 Tahun di Kelurahan Kebalen Kecamatan Babelan Kabupaten Bekasi. Jakarta: Universitas Islam Syarif Hidayatulah (diakses 27 Mei 2019)

Maltida, 2018. Kecanduan Media Sosial dengan Kualitas Komukasi Interpersonal Pada Usia Dewasa Awal. Diakses pada 23 Mei 2019

Narwoko, J. Dwi \& Suyanto, Bagong. 2004. Sosiologi Teks Pengantar dan Terapan, Jakarta: Prenada Media.

Nurudin. 2012. Media Sosial Baru dan Munculnya Revolusi Proses Komunikasi. Yogyakarta: Buku Litera.

McQuail, Denis. 2011. Teori Komunikasi Massa. Jakarta: Salemba Humanika. 
e-Journal Pendidikan Sosiologi Universitas Pendidikan Ganesha

Jurusan Sejarah, Sosiologi dan Perpustakaan (Volume 2, Nomor 2, Tahun 2020)

Pescosolido, Bernice A, (2006). The Sociology of Social Networks, $21^{\text {st }}$ Century Sociology. Sage Publication 2011

Rusmana, 2015. Penipuan Interaksi Melalui Sosial Media. Jurnal Kajian Informasi \&

Perpustakaan Vol.3/No.2,

Desember 2015, hlm. 187-194

Soekanto, Soerjono. 2014. Sosiologi Suatu Pengantar. Jakarta: PT. Raja Grafindo Persada.

Soekanto, Soerjono \& Sulisttyowati Budi. 2015. Sosiologi Suatu Pengantar. Depok: PT Rajagrafindo Persada

Sunarto, Kamanto. 1993. Pengantar Sosiologi. Jakarta: Lembaga Penerbitan Fakultas Ekonomi Ul.

Sinaga H. Dina. 2016. Tingkat Ketergantungan Pengguna Media Sosial Dan Perilaku

Komunikasi (Studi Korelasional Mengenai Pengaruh Tingkat Ketergantungan Pengguna Media Sosial Instagram dan Path Terhadap Perilaku Komunikasi Mahasiswa FISIP USU Angkatan 2016) Medan: Universitas Sumatera Utara (diakses 27 Mei 2019)

Timbowo, Deify. 2016. Manfaat Penggunaan Smartphone Sebagai Media Komunikasi. Universitas Sam Ratulangi, online,

(http://ejournal.unsrat.ac.id/index. php/actadiurna/article/viewFile/11 719/11312.(diakses 24 Mei 2019).

Rahayuni Gst. dkk. 2015 Pengaruh Penggunaan Media Sosial Terhadap InteraksiSosial Pada Sekaa Teruna Desa Adat Kuta, Badung, Bali. Diakses pada 23 Mei 2019

\author{
Republik Indonesia. 2008. Undang- \\ Undang No. 11 tahun 2008 \\ tentang Informasi dan Transaksi \\ Elektronik (ITE). Sekretariat \\ Indonesia. Jakarta.
}

